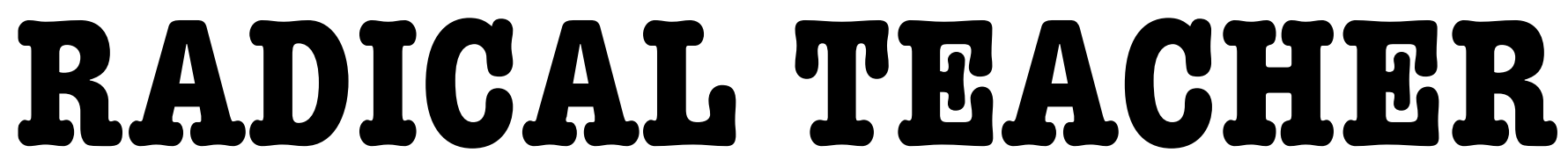

A SOCIALIST, FEMINIST, AND ANTI-RACIST JOURNAL ON THE THEORY AND PRACTICE OF TEACHING

\title{
Critical Teaching and Everyday Life
}

(RADICAL TEACHER NO.20, 1982)

by Buzz Alexander

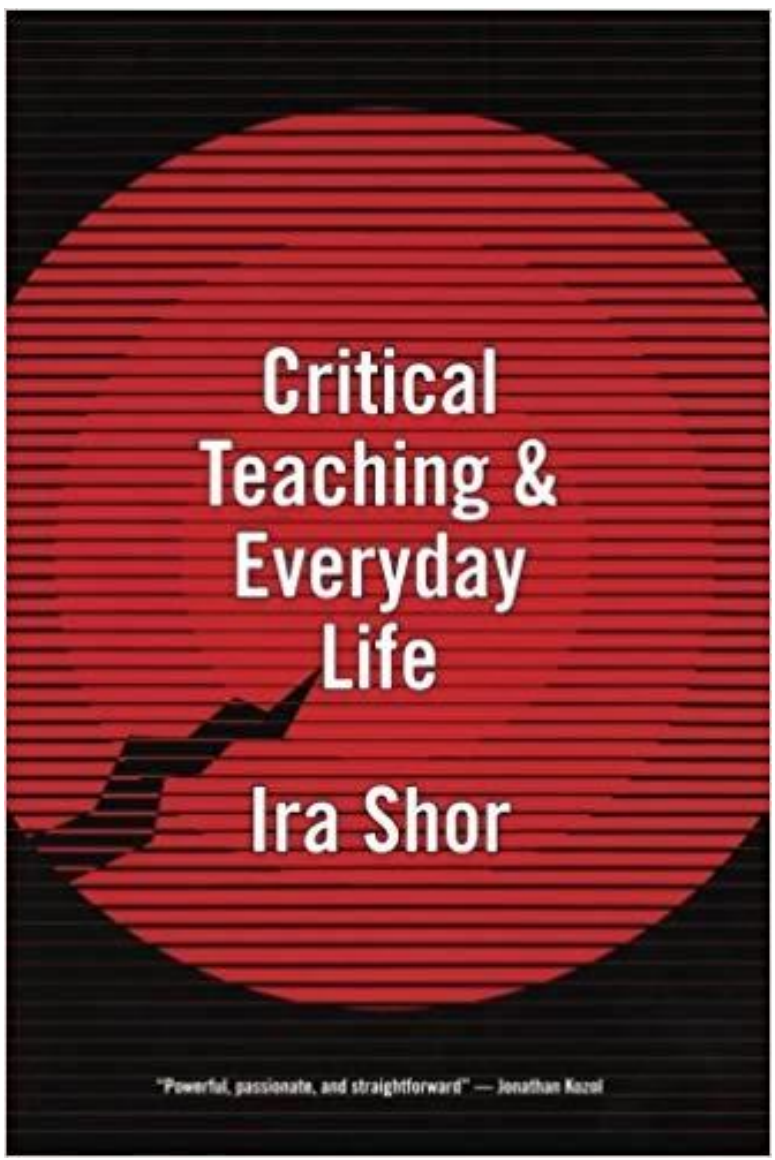

CRITICAL TEACHING \& EVERYDAY LIFE BY IRA SHOR (UNIVERSITY OF CHICAGO PRESS, 1980) 
Critical Teaching and Everyday Life. Ira Shor. South End Press.

$\mathrm{S}$ hor's book and teaching begin with an analysis of the community college, both generally and as he knew it during open admissions in New York: the economics of its establishment, the politics of its architecture, the students it serves, and how it serves them. Then he sketches out in general and demonstrates in stimulating detail an education for critical consciousness. He teaches from the everyday lives of the students -- their work, relationships, consumption habits -- and he practices a pedagogy of active student participation which involves the "withering away" of the teacher into an engaged and responsible facilitator and fellow participant in the learning process, as students work together and assert themselves in their education. A course moves from analysis of particulars -- a chair, one's worst job -- to various levels of abstraction and generalization, and Shor's knowledge of pre-writing, voicing, dialoguing, and drafting aid in making writing a shared, challenging experience for initially indifferent and even hostile students. Student-generated projects include the writing of marriage contracts and the rewriting of the college's stated Mission. The results in learning atmosphere and in students taking on responsibility for their own learning, lives, and society are remarkable and exciting. This book is the most substantial available presentation of methods for transferring Paulo Freire's pedagogy from the third to the first world.

After investigating George Steiner's questions about the viability of language and literature in the face of the Nazi experience, Stanley Milgram's experiments in obedience to authority, Richard Ohmann's radical critique of English teaching and use in America, and Freire's pedagogy, we came, in a core course for Doctor of Arts students (mostly community college teachers) at the University of Michigan, to Shor's book. The earlier texts established problems and possibilities, but nothing very concrete for the American college classroom, and Shor's work was vital. Most of the DAs who were teaching at the time immediately made dramatic changes in their classroom approaches and now talk of the results as being central to their thinking about education. They invited Shor to campus and with him raised questions that took us all beyond the book. The book is essential for teachers looking for reformulation of and recommitment to their teaching, whether on a radically political basis or not. Undergraduates who have worked with me in my course on Vietnam and film insist that I assign it as reading for my small-group facilitators, both because of its explanation of the politics of education and because of its strategies for student generated learning.

$(\mathrm{cc}) \mathrm{BY}-\mathrm{NC}-\mathrm{ND}$

ULLS D-Sonle
This work is licensed under a Creative Commons Attribution-Noncommercial-No Derivative Works 3.0 United States License.

This journal is published by the University Library System of the University of Pittsburgh as part of its D-Scribe Digital Publishing Program, and is cosponsored by the University of Pittsburgh Press. 